\title{
BÁO CÁO BATRƯỜNG HỢP VẾT THƯƠNG TIM TẠI BỆNH VIỆN ĐA KHOA TỈNH BẮC NINH
}

\section{TóM TẮT}

Vết thương tim là một bệnh cảnh ít gặp, bệnh cảnh lâm sàng thường diễn biến rất nhanh và nặng nề, nguy cơ tử vong cao. Vết thương tim nếu được chẩn đoán và phẫu thuật kịp thời thì tỉ lệ cứu sống bệnh nhân tương đối cao. Chúng tôi xin báo cáo 3 trường hợp vết thương tim được xử trí thành công tại bệnh viện đa khoa tỉnh Bắc Ninh.

Tù̀ khóa: vết thuoong tim, các đường mở ngục

\section{I.ĐĂT VẤN ĐỀ}

Vết thương tim là những tổn thương tại tim gây ra do những vật sắc nhọn, những tổn thương này thông với môi trường bên ngoài. Được coi là một tối cấp cứu trong ngoại khoa, vết thương tim là ưu tiên số 1 trong chẩn đoán, vận chuyển và xử lý.Ở Việt Nam, nguyên nhân gây vết thương tim hay gặp nhất là do bạch khí. Đối với vết thương tim do bạch khí, nếu bệnh nhân còn sống khi đến viện thì chẩn đoán không quá khó và phẫu thuật cấp cứu khâu vết thương tim mang lại kết quả tốt cho trên 90\% số bệnh nhân [1] [2] [3].

Đối với các vết thương do bạch khí, tâm thất phải là vị trí buồng tim hay bị thương tổn nhất (> 50\% ), rồi đến tâm thất trái, tâm nhĩ phải. Rất hiếm gặp vết thương ở tâm nhĩ trái [1] [4].Thương tổn phổi hợp hay gặp là tổn thương khoang màng phổi, ổ bụng, cơ hoành ... làm thay đổi đáng kể bệnh cảnh lâm sàng của vết thương tim. Chúng tôi báo cáo 3 trường hợp vết thương tim được phẫu thuật thành công tại bệnh viện đa khoa tỉnh Bắc Ninh.

\section{CA LÂM SÀNG}

\subsection{Case 1:}

Bệnh nhân nam 42 tuổi, vào viện vì đau
Nguyễn Xuân Kiên ${ }^{*}$, Đặng Quang Huy ${ }^{* *}$ ngực, khó thở sau khi bị đâm.Bệnh nhân có tiền sử nghiện ma túy nhiều năm. Trước vào viện khoảng 1 tiếng bệnh nhân bị người khác dùng dao nhọn đâm vào ngực trái. Bệnh nhân vào viện trong tình trạng lơ mơ, đau vùng ngực trái dữ dội, khó thở, da niêm mạc nhợt, mạch 100 lần/phút, huyết áp 100/60 mmHg, 01 vết thương vùng mũi ức dài khoảng $2 \mathrm{~cm}$, bờ sắc gọn, rỉ rả máu.Tim nhịp nhanh, đều, không thấy tiếng bệnh lý. Phổi rì rào phế nang bên phải giảm nhiều. $\mathrm{SpO} 2: 90 \%$. Xquang tại giường: mờ toàn bộ trường phổi phải.Siêu âm tim qua thành ngực tại giường thấy màng ngoài tim có dịch chỗ dày nhất $17 \mathrm{~mm}$. Khoang màng phổi phải có dịch dày $34 \mathrm{~mm}$.Kết quả công thức máu: RBC: 3,31 T/L, HGB: 9,8 g/L, HCT: $29,6 \%$.

Bệnh nhân được mổ cấp cứu xử lý vết thương tim. Mở ngực khoang liên sườn 5 trước bên trái cắt qua xương ức sang bên phải. Mở màng tim thấy 01 vết thương vùng thất phải kích thước $1 \times 1 \mathrm{~cm}$, mép gọn, máu phun thành dòng qua vết thương. Khâu vết thương bằng 02 sợi prolen 4.0 có miếng đệm màng tim.Bệnh nhân thở máy 5 ngày, ra viện sau 2 tuần. Không phát hiện bất thường trên siêu âm tim qua thành ngực tại thời điểm ra viện và khám lại sau 1 tháng.

* Bệnh viện đa khoa tỉnh Bắc Ninh

** Bệnh viện Tim Hà Nội

Người chịu trách nhiệm khoa học: BS. Nguyễn Xuân Kiên

Ngày nhận bài: 01/11/2019 - Ngày Cho Phép Đăng: 20/12/2019

Phản Biện Khoa học: PGS.TS. Đặng Ngọc Hùng GS.TS. Lê Ngoc Thành 


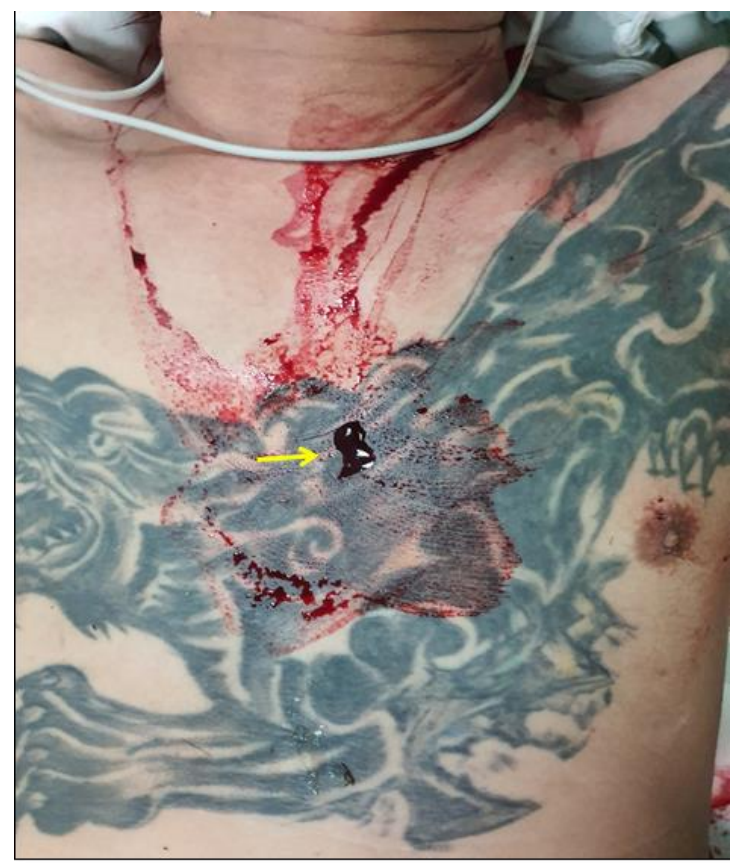

Hình 1: Vết thương vùng nguy hiểm của tim

\subsection{Case 2}

Bệnh nhân nam 59 tuổi, vào viện vì đau ngực, khó thở sau khi bị đâm.Bệnh nhân tiền sử khỏe mạnh. Trước vào viện khoảng 1 tiếng bệnh nhân bị người khác dùng dao nhọn đâm vào ngực trái. Bệnh nhân vào viện trong tình trạng đau vùng ngực dữ dội, khó thở nhẹ, da niêm mạc nhợt, mạch 95 lần/phút, huyết áp 70/40 mmHg, 01 vết thương ngực trái tại khoang liên sườn 5 cách ức trái khoảng $2 \mathrm{~cm}$, bờ sắc gọn. Tràn khí dưới da thành ngực trái.Tim nhịp nhanh, đều, không thấy tiếng bệnh lý. Phổi rì rào phế nang bên trái giảm nhiều. $\mathrm{SpO} 2$ : 92\%. CT lồng ngực không tiêm thuốc cản quang cho thấy tràn dịch màng tim $7 \mathrm{~mm}$ và tràn dịch màng phổi trái 27 mm. Công thức máu: RBC: 4,0 T/L, HGB: 12,4 g/L, HCT: $37,4 \%$.

Bệnh nhân đượcchỉ định mổ cấp cứu xử lý vết thương tim. Mở ngực khoang liên sườn 5 trước bên trái. Mở màng tim thấy 01 vết thương vùng phễu của thất phải kích thước $1 \times 1 \mathrm{~cm}$, mép gọn, đã cầm máu do cục máu đông. Khâu vết thương bằng 02 sợi prolen 4.0 có miếng đệm màng tim.Sau mổ bệnh nhân được rút máy thở sau 9 ngày, ra viện muộn do nhiễm trùng vết mổ thành ngực. Không có bất thường trên siêu âm tim qua thành ngực tại thời điểm ra viện và khám lại sau 1 tháng.

\subsection{Case 3}

Bệnh nhân nam 31 tuổi, vào viện vì đau ngực dữ dội, khó thở do bị đâm kéo vào ngực trái cách 1 giờ. Bệnh nhân vào viện trong tình trạng lơ mơ, đau vùng ngực dữ dội, khó thở, da niêm mạc nhợt, mạch nhanh nhỏ, huyết áp không đo được, 01 vết thương ngực trái kích thước khoảng $1 \times 0,5 \mathrm{~cm}$ tại khoang liên sườn 4 cách ức trái khoảng $2 \mathrm{~cm}$, bờ sắc gọn. Tim nhịp nhanh, không thấy tiêng thổi. Phổi rì rào phế nang bên trái giảm nhiều. SpO2: 88 - 89\%. Siêu âm tim qua thành ngực tại giường thấy khoang màng tim có dịch tại mỏm dày $21 \mathrm{~mm}$, thành bên dịch dày $10 \mathrm{~mm}$. Xquang ngực: không thấy tràn dịch, tràn khí màng phổi hai bên. Công thức máu: RBC: 4,3 T/L, HGB: 12,0 g/L, HCT: 35,2\%.

Bệnh nhân được chỉ định mổ cấp cứu xử lý vết thương tim. Mở ngực khoang liên sườn 5 trước bên trái thấy vết thương xuyên qua khoang liên sườn 5 vào khoang màng tim, mở màng tim thấy 
01 lỗ thủng tâm thất phải kích thước khoảng $1 \mathrm{~cm}$ x $0,5 \mathrm{~cm}$ bằng 01 mũi chỉ Prolen 3.0 có miếng đệm màng tim. Bệnh nhân thở máy 1 ngày, ra viện sau 1 tuần. Không có bất thường được ghi nhận trên siêu âm tim qua thành ngực lúc ra viện và sau khám lại 1 tháng.

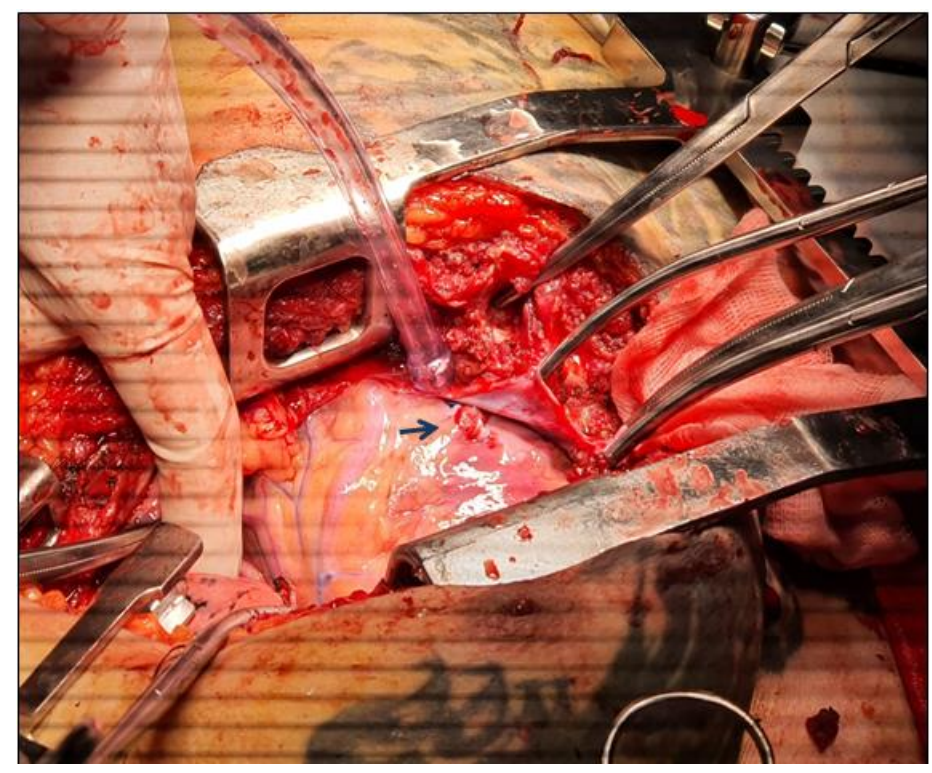

\section{BÀN LUẬN}

Vết thương tim được coi là một tối cấp cứu trong ngoại khoa, được ưu tiên số 1 trong chẩn đoán, vận chuyển và xử trí.Chẩn đoán vết thương tim không quá khó nhưng cần phải chẩn đoán thật sớm để đưa ra những phương án hồi sức và chuẩn bị phẫu thuật cho bệnh nhận. Một số nghiên cứu cho thấy, thời gian từ khi bị chấn thương đến khi phẫu thuật càng kéo dài thì tỉ lệ tử vong càng cao [5] [6].

Về chẩn đoán, vết thương thành ngực, đặc biệt là những vết thương ở vùng nguy hiểm của tim.Hội chứng sốc mất máu hoặc hội chứng chèn ép tim cấp.Cận lâm sàng: chủ yếu dựa vào Xquang và siêu âm tim. Xquang: bóng tim to, trung thất rộng, có khí trong khoang màng tim, có dị vật trong khoang màng tim, tràn máu tràn khí trong khoang màng phổi.Siêu âm tim: dịch màng tim, dịch màng phổi. ngoài ra còn có thể đánh giá các tổn thương tại tim.Cả ba bệnh nhân của chúng tôi đều có những triệu chứng lâm sàng rất điển hình của vết thương tim. Vết thương tại tam giác tim kèm theo các triệu chứng đau ngực dữ dội, khó thở, rối loạn huyết động.Ba bệnh nhân được của chúng tôi được sử dụng các cận lâm sàng chụp cắt lớp vi tính, siêu âm cấp cứu tại giường và chụp Xquang tại giường để chẩn đoán và điều trị. Cả 3 phương pháp này đều có thể góp phần giúp chẩn đoán sớm vết thương tim. Nhưng hạn chế của cả 3 phương pháp cận lâm sàng này là chưa đánh giá được hết tổn thương tại tim như van tim, vách liên thất... từ đó đưa ra phương pháp phẫu thuật hợp lý với từng loại tổn thương. Vì vậy, siêu âm tim là một cận lâm sàng rất quan trọng trong việc chẩn đoán và điều trị vết thương tim.

Việc lựa chọn đường mổ cũng đóng vai trò rất quan trọng đối với cơ sở y tế đa khoa. Lựa chọn đúng đường mổ sẽ giúp các bác sĩ tiếp cận được với vị trí vết thương chính xác để có thể cầm máu và xử trí vết thương. Theo Nguyễn Hữu Ước thì đường mở ngực phụ thuộc vào vị trí vết thương và toàn trạng của bệnh nhân.Đường mở ngực trước bên trái: Khi lỗ vào của vết thương nằm ở ngực trái, cách bờ trái xương ức $>2$ $\mathrm{cm}$.Đường mở dọc giữa xương ức khi lỗ vào của vết thương nằm ở giữa bờ phải của xương ức tới cách bờ trái xương ức $2 \mathrm{~cm}$.Đường mở ngực trước bên phải: khi lỗ vào của vết thương nằm ở bên phải cách xa bờ phải xương ức.Trường hợp 
thương tổn nặng, nguy cơ phải sử dụng tuần hoàn ngoài cơ thể thì tốt nhất nên chọn đường mở dọc giữa xương ức, hoặc đường mở khoang liên sườn 5 cắt qua xương ức sang bên đối diện [7].

Do cơ sở của chúng tôi chưa có phương tiện cưa xương ức nên đối với bệnh nhân thứ 1 , vết thương nằm ở ngay mũi ức, chúng tôi đã chọn đường mở hai bên ngực tại khoang liên sườn 5 cắt qua xương ức. Đối với bệnh nhân thứ 2 và thứ 3 , vết thương cách bờ trái xương ức $2 \mathrm{~cm}$, chúng tôi đã lựa chọn đường mổ qua khoang liên sườn 5 phía trước bên trái.

Một vấn đề nữa cần quan tâm tới là việc xử trí thương tổn tại tim. Những bệnh nhân bị vết thương tâm thất phải hầu hết có thể cứu được trong khi những bệnh nhân bị chấn thương nhiều buồng có tỷ lệ tử vong rất cao [8]. Đối với ba bệnh nhân chúng tôi gặp phải, vết thương nằm ở vùng thất phải, không gây tổn thương mạch vành và tổn thương van tim nên chúng tôi đã xử trí bằng khâu vết thương bằng mũi chữ $U$ với chỉ prolen 4.0 có miếng đệm màng tim. Nhưng đối với một cơ sở y tế không có chuyên khoa phẫu thuật tim mạch, thì việc xử lý vết thương tại tim phải hết sức lưu ý nếu vết thương có tổn thương mạch vành, van tim, thủng vách liên thất, tổn thương các cuống mạch lớn...

\section{KẾT LUẬN}

Vết thương tim là một thương tổn rất nặng, đe dọa tính mạng bệnh nhân. Việc chẩn đoán sớm và đưa ra phương án phẫu thuật hợp lý sẽ giúp chúng ta có thể xử trí kịp thời để cứu sống bệnh nhân.

\section{TÀI LIẾU THAM KHẢO}

1. N. H. Ước, bài giảng vết thương tim và chấn thương tim.

2. P. T. Nam, xử trí cấp cứu vết thương tim, 2015.

3. S. Topaloglu, Penetrating trauma to the mitral valve and ventricular septum. Tex Heart Inst J 2006, 33:392-395.

4. D. Clarke, Emergency operation for penetrating thoracic trauma in a metropolitan surgical service in South Africa. J Thorac Cardiovasc Surg 2011, 142:563-568.

5. A. Tang, Postdischarge complications after penetrating cardiac injury: a survivable injury with a high postdischarge complication rate. Arch Surg 2011, 146:1061-1066.

6. J. Baker, Use of cardiopulmonary bypass to salvage patients with multiple-chamber heart wounds. Arch Surg 1998, 133:855-860.

7. N. H. Ước, Các đường mở ngực trong cấp cứu", Phẫu thuật cấp cứu tim mạch và lồng ngực", ngoại khoa 43 - 52 . 